\title{
Rethink about Heritage Language Learning: A Case Study of Children's Mandarin Chinese learning at a Community Language School in Ontario, Canada
}

\author{
XIAOXIAO DU \\ Western University
}

\begin{abstract}
On-going knowledge mobilization and migration take place on a daily basis in the globalized world. Canada is a multilingual and multicultural country with a large number of visitors and immigrants. One in five Canadian speaks a foreign language other than English and French (Postmedia News, 2012). This case study examined six-year-old Chinese children's heritage language learning in a community school from multiliteracies perspective using observations, interviews, and artefacts to understand children's literacy learning. The findings indicated that Chinese children's literacy learning was not in the traditional repetitive way but involved multimodal communication at school. Useful implications are made for heritage language educators regarding ways to support meaningful heritage language teaching and learning.
\end{abstract}

\section{Introduction}

Canada is a multilingual and multicultural country with a large number of visitors and immigrants. In 2014, there were 260,404 immigrants coming to Canada for diverse economic, humanitarian and educational reasons (Citizenship and Immigration Canada, 2015). The People's Republic of China is one of the top immigration source countries and the Chinese language is one of the top three frequently spoken mother tongues at home (CIC, 2015). It is for these reasons that educators need to understand Chinese children's schooling in Canada. Many studies have examined immigrant children's English learning at home and school (Anderson, \& Chen, 2013; Campbell, 2000; Carhill, Suarez-Orozco, \& Paez, 2008; Chen, Geva, \& Schwartz, 2012; Hao, Chen, Dronjic, Shu, \& Anderson, 2013; Menard-Warwick, 2009; Sadowski, 2004) as well as their Chinese learning at home and at weekend schools (Brinton, Kagan, \& Bauckus, 2008; Comanaru \& Noels, 2009; Duff \& Li, 2009; Kondo-Brown \& Brown, 2007; Norton, 2013; Xiao, 2006; Zhang, 2009). While the literature has documented traditional forms of learning such as learning to read and write through repeated practice (e.g., Han, \& Chen, 2010), less is known about children's multimodal ways of Chinese learning. This paper examines Chinese children's heritage language learning from a multimodal lens. My research question is in what ways do Chinese children learn Mandarin Chinese at a community heritage language school that operates according to the school calendar days? Next, I present the theoretical perspectives that guide this study. 


\section{Theoretical Perspectives}

\section{Socio-cultural Perspective of Literacy}

This study views literacy from a socio-cultural perspective that is literacy learning is socially and culturally situated. "A sociocultural approach concerns the ways in which human action, including mental action (e.g. reasoning, remembering), is inherently linked to the cultural, institutional and historical settings in which it occurs" (Wertsch, 1994, p. 203). The sociocultural approach focuses on putting literacy and learning into social, cultural, and historical contexts and emphasizing the active role of children in language socialization. In brief, literacy is socially and culturally constructed in contexts.

In particular, this study is situated in the multiliteracies framework (New London Group, 1996) and considers literacies as multiple (e.g. multilingual, multicultural, and multimodal). Chinese children living in Canada constantly use both English and Chinese in their daily life. And within the Chinese language there can be different dialects of Chinese (e.g. Mandarin and Cantonese) and different written literacies (e.g. simplified Chinese characters used in mainland China and complicated traditional ones used in Hong Kong). For example, it is common for children to use their mother tongue at home and communicate with teachers and friends in English at school. Furthermore, Chinese children explicitly and implicitly draw upon their cultural background in their daily communication and literacy learning process. Culture plays a significant part in children's literacy learning (e.g., Cole, 1996; Gregory, Long \& Volk, 2004; Pahl \& Rowsell, 2010; Razfar \& Gutierrez, 2003). A sociocultural perspective interprets culture "as non-normative, non-integrated, and dynamic in which culture is instantiated in the practices and material conditions of everyday life" (Razfar \& Gutierrez, 2003, p. 35). Culture is constructed, developed, practiced, cultivated, and maintained in different activities including literacy learning (Razfar \& Gutierrez, 2003). For example, children attending the community language school in this study celebrated Thanksgiving by making Thank-you cards and they also learned to show great respect to teachers at school by learning the Chinese school song. Finally, the act of literacy learning and meaning making involves using multiple modes for different communicative purposes. Jewitt and Kress (2003) define mode as "a regularized, organized set of resources for meaning-making, including, image, gaze, gesture, movement, music, speech, and sound-effect" (p. 1). They point out that "a multimodal approach to learning requires [researchers] to take seriously and attend to the whole range of modes involved in representation and communication" (p. 1). When people communicate with each other or engage with different texts in different contexts, they make use of more than one mode. For example, in the study, Ms. Zhang and the children used their hand movement and water sounds to express how they understood the Chinese character 水 (water). Both gesture and sound effect were used in their learning process.

In summary, the multiliteracies perspective embraces the complexity of literacies. It views literacy learning as making uses of different modes (Kress, 2003) to make meaning of the surroundings and effectively communicate with texts and people in different contexts. Chinese children live in and navigate in their multilingual and multicultural worlds using their funds of knowledge (Moll, 1992) and multiple modes (Jewitt \& Kress. 2003) to make sense of the world around them. Learning the Chinese language goes beyond learning to know the Pinyin sound system, read Chinese texts and write Chinese characters, should also include cultural literacy understanding and multimodal communication. 


\section{Heritage Language Learning and Teaching}

There are many ways to understand and define the term of heritage language (HL). According to Park (2013, p. 31), HL was originally defined in Canada as "a language other than one of the official languages of Canada that contributes to the linguistic heritage of Canada" (Canadian Legal Information Institute, 1991, 'Definitions'). Later on, Cummins and Danesi (1990) define HLs in the Canadian context as all languages brought to Canada by immigrants, with the exception of aboriginal languages, English, and French. In this paper, I follow the HL concept from Cummins and Danesi and adopt Park's (2013) idea by understanding HLs as "all languages, except for aboriginal languages, brought to host societies by immigrants" (p. 31). That is, HLs refer to languages brought by immigrants to their host countries other than English, French and Aboriginal languages.

As Li and Wen (2015) have pointed out that many research studies focusing on investigating Asian heritage language education from the cognitive perspective (e.g., Liu et al., 2009), sociocultural perspective (e.g., Lee, 2002; Li, 2007), and psychological perspectives of HL learning (e.g., Liu et al., 2012), less is known about HL teaching and instruction in diverse contexts. Parents play a significant role in supporting their children's HL learning. Parents with positive attitudes tend to spend more time and effort to help their children with HL learning at home or sending them to Chinese schools (Li, 2005; Tsai, Park, Liu, \& Lau, 2012). Teachers also play an important role in children's HL learning. Their ways of teaching will influence students' ways of learning and their motivations to maintain HL. Li (2005) reported that when teachers dominated the teaching process by giving direct and dry instructions of repetitive drills, students did well in HL learning. On the contrast, $\mathrm{Wu}$ (2011) reported that when pedagogically relevant teaching methods (e.g. peer discussions and group activities) were used, students showed more engagement in their HL learning. In brief, the existing literature indicates that traditional heritage teaching methods such as teacher-dominant direct instruction and repetitive exercise are widely used in Chinese heritage teaching and there are teachers who tried to use discussions and group work in their teaching to increase student engagement. In the following section, I will discuss the research design of study by briefly discussing the case study approach, introducing the research site and participants, and explaining the process of data collection and analysis.

\section{Research Design}

I conducted a qualitative case study (Yin, 2003) with the aim to have an in-depth understanding of children's Mandarin Chinese learning at a community heritage language school. A case study approach helps to "portray 'what it is like' to be in a particular situation, to catch the close-up reality and 'thick description' of participants' lived experiences of, thoughts about and feelings for, a situation" (Cohen, Manion, \& Morrison, 2000, p. 181). The research site was a community language school in a highly diverse neighborhood. Six participants participated in the study. I will provide the details of the research site, participants as well as data collection and analysis in the following paragraphs.

\section{The Research Site}

The community heritage language school, hereafter referred to as the Chinese 
school, was housed in a heritage building in a multicultural and multilingual community where a great number of Chinese people lived. The Chinese school functioned as a nonprofit education organization managed by parents. It had been founded in 1994 by the Chinese Scholars Association at the local university to help Chinese parents take care of their children after school and support Chinese children in the neighbourhood to learn the Mandarin Chinese language and Chinese culture. With the development of the Chinese school and demand from parents, a parents' committee consisting of five children's parents plus one principal was founded in 2006 to facilitate communication between parents and teachers and to better serve the Chinese community. According to the teachers and the parents' committee, the goals of this Chinese school were to foster Chinese children's interest in learning Mandarin Chinese, to improve their overall Mandarin Chinese language ability in listening, speaking, reading and writing, as well as to maintain, inherit, and develop a prominent Chinese ethnic culture.

The Chinese school operated according to the calendar of the local public school board. Classes were in session from 3:30 to 5:30 in the afternoon on weekdays. When the Chinese school was first founded, there was only one class. One year later, two classes at the beginning level and intermediate level were established due to the large number of students. At the time of this study, there were 27 students including 12 students at the beginning level and 15 students at the intermediate level. Most students were Chinese and there were four children from other cultures (e.g., European and South American). The tuition was 70 Canadian dollars per month to cover the rent, teachers' salaries, and school supplies.

Every school day afternoon, two Chinese school teachers went to the neighbourhood public school to pick up children and walked with them for about 10 minutes to the Chinese school. The first period of the class was from 4:00 pm to 4:40 pm. It mainly consisted of reviewing and learning new lessons. Recess time was 4:40 pm to 5:00 pm. During recess, weather permitting, children could choose to go outside and play on the playground in the large yard. They could also stay inside and do an activity of their choice such as playing board games and practicing paper folding. The second lesson period was from 5:00 to 5:30 pm. It involved engaging children in learning Mandarin Chinese through literacy activities.

The teachers used both Chinese and English in their teaching. They employed a Chinese subject textbook published by Nanjing Normal University Press. Ms. Q and Ms. Zhang considered this textbook to be suitable for Chinese children to learn Mandarin Chinese or Putonghua outside mainland China because they believed that this book could help children to learn Pinyin and Chinese characters and the Mandarin Chinese language as a whole with appropriate exercises, which were helpful for children to build their confidence in learning the Mandarin Chinese language and Chinese culture. At the Chinese school, children were encouraged to communicate in Mandarin Chinese in class. Since there were children with European and South American heritages, both English and Chinese were used in children's communication with each other. Children at the beginning level learned about three to five new Chinese characters each day and completed a full text each week. They were required to read fluently or to recite certain texts based on their Chinese proficiency levels. There was a monthly quiz on what children had learnt such as writing the Chinese characters from the textbook. 


\section{Participants}

There were six participants including two Chinese teachers, four Chinese children (three boys and one girl). The participants' information is in the following tables.

Table 1

Participating Teachers

\begin{tabular}{|l|l|l|l|}
\hline Pseudonym & Gender & $\begin{array}{c}\text { Teaching } \\
\text { Level }\end{array}$ & \multicolumn{1}{c|}{ Teacher information } \\
\hline Ms. Q & Female & Beginners & $\begin{array}{l}\text { Highest level of education: Bachelor's degrees. } \\
\text { Experience: Ms. Q has been teaching at the } \\
\text { school for the past two years. She also taught } \\
\text { Mandarin Chinese in a weekend heritage } \\
\text { language program. She taught at the Chinese } \\
\text { school after 2008. }\end{array}$ \\
\hline Ms. Zhang & Female & Beginners & $\begin{array}{l}\text { She is a language teacher with fifteen years' } \\
\text { experience teaching in mainland China. She } \\
\text { came to Canada in 2002, and then studied } \\
\text { Early Childhood Education program in the } \\
\text { local college. After she graduated from the } \\
\text { ECE program, she started to work in a in a } \\
\text { daycare center during the day and taught } \\
\text { Mandarin Chinese in the late afternoon at the } \\
\text { Chinese school. She taught at the Chinese } \\
\text { school before 2008. }\end{array}$ \\
\hline
\end{tabular}

Table 2

Participating Children

\begin{tabular}{|c|c|c|c|l|}
\hline Pseudonym & $\begin{array}{c}\text { Birth } \\
\text { place }\end{array}$ & Gender & Grade & Family information \\
\hline Brian & Canada & Male & $\begin{array}{c}\text { Grade } \\
1\end{array}$ & $\begin{array}{l}\text { Brian was the only child in his family. } \\
\text { His father was a doctoral student in } \\
\text { science at the local university and his } \\
\text { mother worked part-time in private } \\
\text { school residences. }\end{array}$ \\
\hline Star & Canada & Male & $\begin{array}{c}\text { Grade } \\
1\end{array}$ & $\begin{array}{l}\text { Star was the only child in his family. } \\
\text { The family is from the northern part of } \\
\text { mainland China and came to Canada } \\
\text { first in 2000 and then again } \\
\text { permanently starting in 2003. }\end{array}$ \\
\hline Eric & Canada & Male & Grade & $\begin{array}{l}\text { Eric had a little sister who was taken } \\
\text { care of by his grandmother. His mother } \\
\text { worked at the local university and his }\end{array}$ \\
\hline
\end{tabular}




\begin{tabular}{|c|c|c|c|l|}
\hline & & & 1 & father owned a convenience store. \\
\hline Samantha & Canada & Female & $\begin{array}{l}\text { Samantha was the only child in her } \\
\text { family. Her father was a post-doctoral } \\
\text { fellow at the local university. Her } \\
\text { mother worked part-time in a local } \\
\text { store. She returned to China at the end } \\
\text { of the school year. }\end{array}$ \\
\hline
\end{tabular}

\section{Data Collection and Analysis}

Data collection included class visits and observations, semi-structured interviews with Chinese teachers, informal conversations with children and their parents, and children's literacy work. All the collected data were coded by date and participant and audio-recorded interviews were transcribed and saved in password-protected word documents. Data were analyzed using interpretational analysis to find emerging themes to understand children's Mandarin Chinese learning (Gall, Gall \& Borg, 2007). I began the data analysis by reviewing all the collect data and then sorted the data into emerging themes (e.g. direct teaching and learning/traditional ways, interactive learning and teaching/multimodal ways) with the goal to answer the research question. Later, I reviewed the themes and looked into the data in each theme to understand the focal children's ways of learning Mandarin Chinese at the Chinese school. In the next section, I present the findings as they relate to my research question: In what ways do Chinese children learn Mandarin Chinese at a community heritage language school?

\section{Findings}

\section{Learning Mandarin Chinese through Gestures and Sounds}

Ms. Zhang taught children to recognize, read, and write Mandarin Chinese characters using a combination of traditional Chinese practices, such as repetitive reading and writing drills, as well as certain multimodal elements, such as gesture, sound effect, and oral presentation. For example, Ms. Zhang used sounds and gestures to teach simple Chinese characters. When she taught 水 (water), she used her hands and sound effects to help children to understand the structure and meaning of this Chinese character. For example, her left hand and right hand were like the left part and right part of 水, and her body was like the middle part of the character. She slightly moved her hands from left to right to demonstrate water movement. Her movement was also accompanied by 哗哗 /sound of water to mimic water sounds. In this way, children were able to get to know how to pronounce the character first by repeating after the teacher, and then learned the meaning of the character and writing of the character through Ms. Zhang's gestures and handwriting. The participating children came to understand that there were three parts of this character 水, the left part and right part were not straight lines but more like moving water, and the middle body one was a straight line. In this way, children were able to recognize, pronounce/read, and write this character through understanding the meaning, the structure of three parts, having opportunities to use gestures and sounds to remember this character and then put all together in their writing practice. This way of teaching Chinese characters is indeed multimodal because the teacher and children used movement, gesture, and sound 
effect to demonstrate their learning process.

Ms. Q also used this approach in her class. For example, when she taught the text titled家 (family), she used a similar strategy to teach the Chinese character of 家, a complex one for grade one children. She asked children to form their own groups and thought of ways to use their body movement to demonstrate their understanding of this character after she taught children the sound and the meaning of this character. In Eric's group, he was the tallest person, so the group members decided to let him stretch his arms straight to make the roof of a house and the other group members were family members "happily live together” 幸福地生活在一起. Eric's group used their body and facial expressions (e.g. smiles) to successfully demonstrate how they understood the meaning and structure of 家. In this activity, multimodal elements were used to help children to recognize and understand the structure and meaning of different Chinese characters. Traditional repeated writing practice still took place in Ms. Zhang's class, but the writing process was no longer boring as children would draw upon their multimodal demonstration process and then put their understanding to writing practice.

\section{Learning Mandarin Chinese through Image and Drawing}

Besides movement, gestures, and sound effect, Ms. Zhang also used image and drawing to help children to practice their reading and writing. Take the teaching of the text titled Sun 太阳 for example (See Figure 1). When Ms. Zhang began to teach a new text, she first picked out new words from the text, and then wrote them on the whiteboard with Pinyin (Chinese sound system). (Please find these new Chinese characters at the left hand corner of the whiteboard in Figure 1.) After that, to get to know how to read each Chinese character, she asked the children to read after her and then she explained their meanings. When the children knew all the new words, she moved on to read the whole text sentence by sentence with children and then explained the meaning of each sentence.

Ms. Zhang then provided an opportunity for children to perform the text in groups. Each group was responsible to present their understanding through actions of one sentence in the text. The first four sentences describe where and how the sun comes out: from the sea, prairie, a village and forest. Children used body movements and gestures to present the action of the sun.

At the end of that week, Ms. Zhang also asked the children to make their own book about this text (Please find the sample in the middle of the whiteboard in Figure 1.) Children were provided opportunities to use their drawings and writing to make their own textbook about Sunrise, a mini book with a book cover and five pages describing five sentences from the text. Children used different shapes and colors to draw the sea, the grass in the prairie, roosters in the village, and birds in the forests to describe sunrise in their own ways. Although the children organized their pages differently, the children used the colours yellow and red to draw the sun. This again shows that children are capable meaning makers who can practically use different colors, shapes and characters to express their ideas.

In brief, Ms. Zhang incorporated drawing into Mandarin Chinese learning. The participating children read the text for understanding, used their drawing and writing to make a mini book, and presented their books to the class. This practice again proves that learning Mandarin Chinese can go beyond repetitive reading and writing activities. Ms. Q did a similar activity when she taught the text titled Family (See Brian's sample in Appendix A). Since children are active knowledge constructors who draw upon what they 
have learned and use elements to represent their context in a tacit way, Brian changed the text regarding family members to reflect his own family context and purposely used the colour red to showcase the red brick wall of his place.

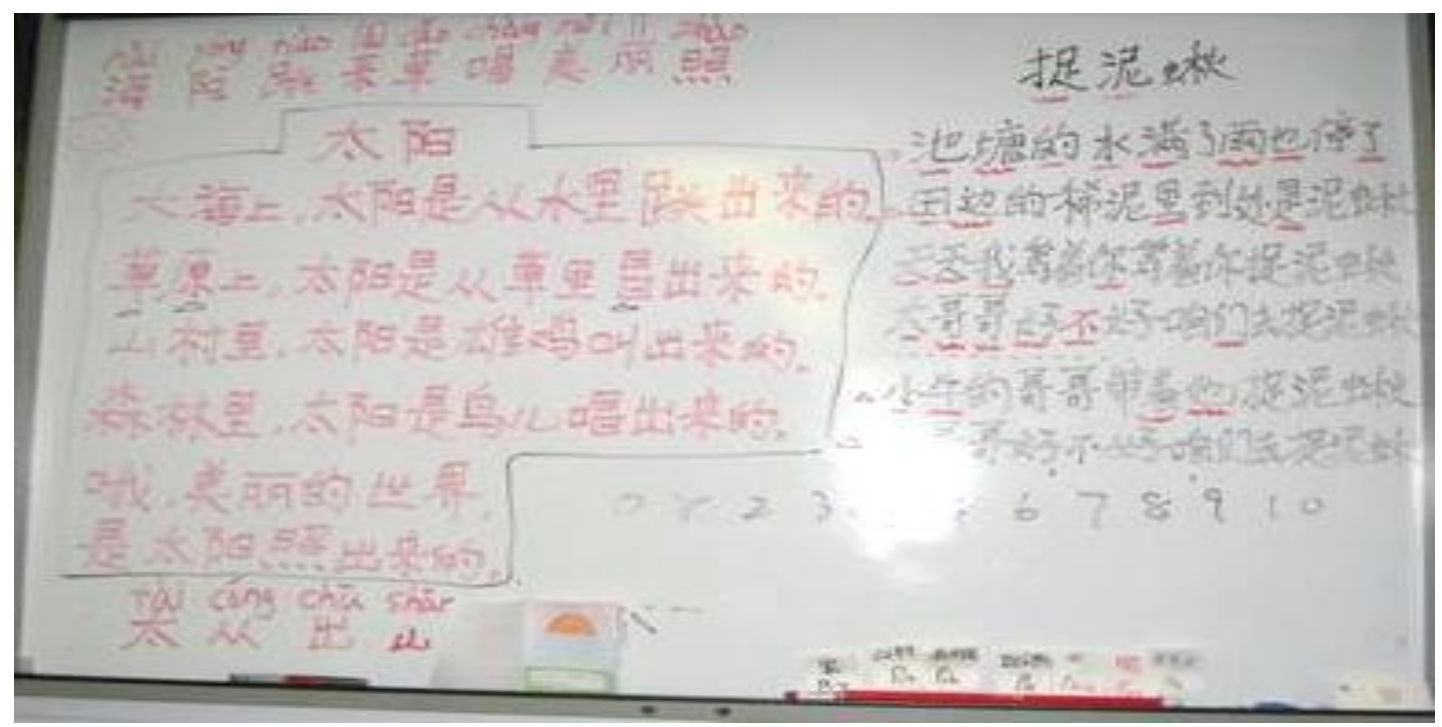

Figure 1. Whiteboard at the Chinese school

\section{Learning Mandarin Chinese through Music}

Ms. Zhang and Ms. Q both used music to teach the children to sing Mandarin Chinese songs in class in order to extend children's vocabulary and enhance their literacy understanding in contexts. Drawing from the interview data, both teachers believed that bringing music to class was an effective way to engage children in reading lyrics and to get to know how to use words in a specific context. Ms. Zhang taught children how to sing Catch the eels 捉泥鳅, a common children's song in China (See lyrics at the right side of the whiteboard in black in Figure 1). The lyrics vividly describe brothers catching eels in the summer. Children learned different location nouns such as lake and field, and different action verbs like wait and catch, as well as how to ask an appropriate question to an elder brother. The lyrics provided a meaningful context for children to practice what they had learned from their Chinese textbook. In summary, learning Mandarin Chinese through music and songs supports children's understanding words, reading text, and practicing language use in contexts. Learning is put into meaningful contexts.

Ms. Q also used her class time to teach children how to sing the Chinese school song. Besides vocabulary learning and reading comprehension, learning the Chinese school song connected children with the embedded Chinese cultural understandings of the role of school, teacher and leaners. In the Lyrics (See Figure 2), the Chinese school was described as a big family where children come together to learn. Teachers were considered as guides who coached children to learn and make progress in their learning. Children were described as trees who, with the teachers' guidance, grow into big and tall trees. In brief, bringing music and singing Chinese songs to Mandarin Chinese learning can help children to understand and appreciate the embedded cultural values of school and teachers to a certain degree such as respecting and studying with teachers, and learning together at school. 
中文学校 快乐学习 你我祥和 聚一起 You and I happily study together at the Chinese school

我们怀着 火热的心 来到这个 大家庭 We come to this big family with warm hearts

你的教导 能使我们 目标更远 向前进 Your teaching can guide us to move forward

你的慈祥 怀抱培育 小树苗长 成大树 Your guidance helps us to grow stronger and taller

Figure 2. The Chinese school song 中文学校校歌

\section{Learning Mandarin Chinese through Craft Making and Nursery Rhymes}

Ms. Zhang made use of craft making to help children to learn Chinese nursery rhymes. For example, when she discovered that some children did not like to eat vegetables, she taught them a nursery rhyme titled a little rabbit 小白兔. Children first learned the nursery rhyme and then discussed the benefits of eating vegetables. In order to make it fun, Ms. Zhang also taught the children how to make a little rabbit using paper (See Appendix B). She first put children in groups. In the group, the children discussed with each other in Chinese regarding who would be doing what and how to put pieces together. Once their rabbits were ready, children presented their work to the whole class. One child recited the rhyme and the other child moved the rabbit up and down to show how it ate carrots and cabbages. In this literacy activity, children practised speaking, reading and communicating with each other using words, sounds and gestures. Besides making paper rabbits, children also made ladybugs (when they learned about this insect) as well as Thank-you cards (around Thanksgiving) to express their gratitude to a particular person. Engaging in craft making to support Chinese learning helps to make the learning process engaging and meaningful. Children's Chinese literacy learning goes beyond simply learning to read a text and includes putting learning into contexts, connecting learning with children's daily life and having group work opportunities to practice their communication and problem solving skills.

Besides getting children to make crafts in support of their Chinese learning, Ms. Zhang also encouraged children to make craft related to common nursery rhymes (e.g., Five Little Monkeys, Mr. Alligator) in order for the children to practice nursery rhymes in groups (See Appendix C). This literacy activity provided an opportunity for parents and children to work together at home to figure out the proper Chinese translations of the above two English nursery rhymes. After their translations were complete, children brought their translations to the class. Each child presented their versions of the translation, and then, following a class discussion, the class decided which version was to be used in their drama presentation. Once a final translation version was chosen, children got to prepare for their drama presentation in groups. Children actively worked in groups, discussing who would be performing which character and how they would get their character to move around. The participating children used different modes of communication including gestures, images, sounds and speech, to present their Chinese version of Five Monkeys and $M r$. Alligator. In this literacy activity, Ms. Zhang and the participating children drew upon what they knew about English versions of the nursery rhymes Five Little Monkeys Jumping on 
the Bed五只小猴子在床上蹦呀蹦 and Mr. Alligator 鳄鱼先生 and incorporated these rhymes into their Chinese learning to make learning engaging and meaningful. In sum, both Chinese and English literacies were involved and more than one mode was used in children's drama show.

\section{Discussions}

The findings of the study indicate that Mandarin Chinese learning can be understood and analyzed from the multiliteracies perspectives, that is, multilingual/bilingual children make use of multiple modes to make sense of the Chinese language and embedded cultural values such as being respectful and grateful. Firstly, all the participating children can be considered as emergent bilinguals in that they had both an English and Mandarin Chinese linguistic knowledge base. With parental support, the children drew upon what they knew in English and Mandarin Chinese to translate two nursery rhymes. The children needed to understand the English version first and then found the Chinese to match the English meaning. At the same time, they also needed to pay attention to uses of rhyming words. In other words, the participating children traveled between English and Chinese literacies to support their translation process. Indeed, literacy needs to be considered as plural, as different literacies (English and Chinese) and diverse aspects of literacies (listening, speaking, reading, writing, and viewing) are involved in the learning process.

Second, literacies are socially and culturally constructed practices and literacy learning can reflect certain cultural understandings. When the children were learning the Chinese school song with Ms. Q and when they were making Thank-you cards with Ms. Zhang, they were learning about the embedded cultural literacies, about the value of school, the role of teachers, and about being thankful as children/learners. Culturally and linguistically diverse children celebrate more than one culture in Canada, that is, they embrace multiculturalism in their own ways.

Thirdly, Mandarin Chinese learning can be multimodal. Ms. Zhang encouraged children to use gestures, sounds, images, and speech to help the participating children understand the meaning and structure of Chinese characters. The children had opportunities to sing Chinese songs, make crafts, and present drama shows. In this way, learning is put into contexts and connected with the learners' interests.

Last but not least, the findings confirm the positive uses of group work and peer discussion (Wu, 2011), but deny the fact that repetitive drills ( $\mathrm{Li}, 2005)$ are the only tools to teach children to learn Mandarin Chinese. Teachers in the study made good use of peer discussion, group communication and oral presentation to help children express ideas using various modes and diverse background knowledge.

\section{Conclusion}

In conclusion, the findings of this study break the traditional stereotypes of Chinese language learning as learning through repeated print literacy activities and indicate that Chinese language learning can be multimodal and engaging. Furthermore, the findings suggest that with limited existing heritage language resources, teachers can be creative in making their own teaching resources by getting children connected with music, crafts and nursery rhyme translation. The findings also signal to teachers that they can critically analyze students' needs and interests, and provide different opportunities and materials to 
scaffold children's multimodal Chinese literacy learning. Finally, parent engagement plays an important role in Mandarin Chinese learning. With a positive attitude and continuous support from parents, children may be more likely to maintain their heritage language learning. Possible implications for heritage language teachers are getting to know your students, making good use of existing materials, drawing upon parental support, creating meaningful and engaging lessons using multiple modes in teaching as well as getting ready to be creative in your way as you know your context the best.

\section{References}

Anderson, R. C., \& Chen, X. (2013). Chinese reading development in monolingual and bilingual learners: Introduction to the special Issue. Scientific Studies of Reading, $17,1-4$.

Brinton, D., Kagan, O., \& Bauckus, S. (2008). Heritage language acquisition: A new field emerging. New York, NY: Routlege.

Campbell, R. (2000). Heritage language. In J. W. Rosenthal (Ed.), Handbook of undergraduate second language education (pp. 165-184). Mahwah, NJ: Lawrence Erlbaum.

Canadian Legal Information Institute. (1991, February 01). Canadian heritage languages institute art. Retrieved December 15, 2010, from http://www.canlii.org/en/ca/laws/stat/sc-1991-c-7/latest/sc-1991-c-7.html

Carhill, A., Sua'rez-Orozco, C., \& Paez, M. (2008). Explaining English language proficiency among adolescent immigrant students. American Educational Research Journal, 45(4), 1155-1179.

Chen, X., Geva, E., \& Schwartz, M. (2012). Understanding literacy development of language minority students: an integrative approach. Reading and Writing, 25, 1797-1804.

Citizenship and Immigration Canada. (2015). Facts and Figure: Immigration Overview: Permanent Residents Canada (2014). Retrieved September 5, 2015, from http://www.cic.gc.ca/english/resources/statistics/facts2014/index.asp

Cohen, L., Manion, L., \& Morrison, K. (2000). Research methods in education ( $5^{\text {th }}$ ed.). New York, NY: Routledge.

Cole, M. (1996). Cultural Psychology. Cambridge, MA: Harvard University Press.

Comanaru, R., \& Noels, K.A. (2009). Self-determination, motivation, and the learning of Chinese as a heritage language. Canadian Modern Language Review, 66, 131158.

Cummins, J., \& Danesi, M. (1990). Heritage languages: The development and denial of Canada's linguistic resources. Toronto, Ontario, Canada: Our Schools/Our Selves Education Foundation.

Duff, P. A., \& Li, D. (2009). Indigenous, Minority, and Heritage Language Education in Canada: Policies, Contexts, and Issues. The Canadian Modern Language Review/La Revue canadienne des langues vivantes, 66(1), 1-8.

Gall, M. D., Gall, J. P., \& Borg W. R. (2007). Educational research: An introduction $\left(8^{\text {th }}\right.$ ed.). New York, NY: Pearson Education Inc.

Gregory, E., Long, S. \& Volk, D. (Eds.) (2004). Many pathways to literacy: young children learning with siblings, grandparents, peers and communities. New York, NY: Routledge Falmer. 
Han, Z., \& Chen, C. A. (2010). Repeated-reading-based instructional strategy and vocabulary acquisition: A case study of a heritage speaker of Chinese. Reading in a Foreign Language, 22(2), 240-262.

Hao, M., Chen, X., Dronjic, V., Shu, H., \& Anderson, R. C. (2013). Chinese children's development of morphological awareness. Applied Psycholinguistics, 34, 45-67.

Jewitt, C., \& Kress G. (Eds.) (2003). Multimodal Literacy. New York, NY: Peter Lang Publishing Inc.

Kondo-Brown, K., \& Brown, J. D. (2007). Introduction. In K. Kondo-Brown \& J. D. Brown (Eds.), Teaching Chinese, Japanese, and Korean heritage language students: Curriculum needs, materials, and assessment (pp. 3-16). New York, NY: Lawrence Erlbaum Associates.

Lee, J. S. (2002). The Korean language in America: The role of cultural identity in heritage language learning. Language, Culture and Curriculum, 15(2), 117-133.

Li, G. (2007). The role of parents in heritage language maintenance and development: Case study of Chinese immigrant children's home practices. In K. Kondo-Brown (Eds.), Heritage language development: Focus on East Asian immigrants (pp. 1532). Amsterdam, the Netherlands: John Benjamins.

Li, G., \&Wen, K. (2015). East Asian Heritage Language Education for a Plurilingual Reality in the United States: Practices, Potholes, and Possibilities. International Multilingual Research Journal, 9(4), 274-290.

Li, M. (2005). The role of parents in Chinese heritage-language schools. Bilingual Research Journal, 29(1), 197-207.

Liu, L. L., Benner, A. D., Lau, A. S., \& Kim, S. Y. (2009). Mother-adolescent language proficiency and adolescent academic and emotional adjustment among Chinese American families. Journal of Youth and Adolescence, 38(4), 572-586.

Liu, L. L., Wang, S. W., Fung, J., Gudiño, O. G., Tao, A., \& Lau, A. S. (2012). Psychology of Asian American children: Contributions of cultural heritage and the minority experience. In E. C. Chang \& C. A. Downey (Eds.), Handbook of race and development in mental health (pp. 147-167). New York, NY: Springer.

Menard-Warwick, J. (2009). Gendered identities and immigrant language learning. Clevedon, UK: Multilingual. Matters。

Moll, L. C. (1992). Literacy research in community and classrooms: A sociocultural approach. In R. Beach, J. L. Green, M. L. Kamil \& T. Shanahan (Eds), Multidisciplinary perspectives on literacy research. Urbana, IL: National Conference on Research in English and National Council of Teachers of English.

New London Group. (1996). A pedagogy of multiliteracies: Designing social futures. Harvard Educational Review, 66(1), 60-92.

Norton, B. (2013). Identity and language learning: Extending the conversation (2nd ed.). Bristol, UK: Multilingual Matters.

Pahl, L., \& Rowsell, J. (2010). Artifactural literacies: Every object tells a story. New York, NY: Teachers College Press.

Park, S. M. (2013). Immigrant students' heritage language and cultural identity maintenance in multilingual and multicultural societies. Concordia Working papers in Applied Linguistics 4, 30-53.

Postmedia News. (2012, October 24). Canada Census: One in five speaks a foreign language at home. National Post. Retrieved from 
http://news.nationalpost.com/2012/10/24/canada-census-one-in-five-speaks-aforeign-language-at-home/

Razfar, A., \& Gutierrez, K. (2003). Reconceptualizing early childhood literacy: The sociocultural influence. In N. Hall, J. Larson \& J. Marsh (Eds.). Handbook of Early Childhood Literacy (pp. 34-47). London, UK: Sage.

Sadowski, M. (2004). Teaching Immigrant and Second-Language Students: Strategies for Success. Cambridge, MA: Harvard Education Press.

Tsai, K. M., Park, H., Liu, L. L., \& Lau, A. S. (2012). Distinct pathways from parental cultural orientation to young children's bilingual development. Journal of Applied Developmental Psychology, 33(5), 219-226.

Wertsch, J. V. (1994). The primacy of mediated action in sociocultural studies. Mind, Culture and Activity, 1(4), 202-208.

Wu, H. P. (2011). Constructing culturally relevant pedagogy in Chinese heritage language classrooms: A multiple-case study. US-China Education Review, B(7), 939-952.

Xiao, Y. (2006). Heritage learners in the Chinese language classroom: Home background. Heritage Language Journal, 4(1), 47-57.

Yin, R. K. (2003). Case study research: Design and methods ( $3^{\text {rd }}$ ed.). Thousand Oaks, London, New Delhi: Sage Publications.

Zhang, J. L. (2009). Chinese senior high school EFL students' metacognitive awareness and reading-strategy use. Reading in a Foreign Language, 21(1), 37-59.

\section{Author Biography}

Dr. Xiaoxiao Du has been working with culturally and linguistically diverse students and their families for over 10 years. Her research interests include language and literacy, multilingualism, multiculturalism, multiliteracies, English as an additional language learning and teaching, culture adjustment, identity construction, heritage language education, and international \& comparative education. She has presented at different international and national conferences as well as shared her research studies in book chapters, conference proceedings, journals, and newsletters. 


\section{Appendices}

Appendix A: Brian's literacy sample titled My family

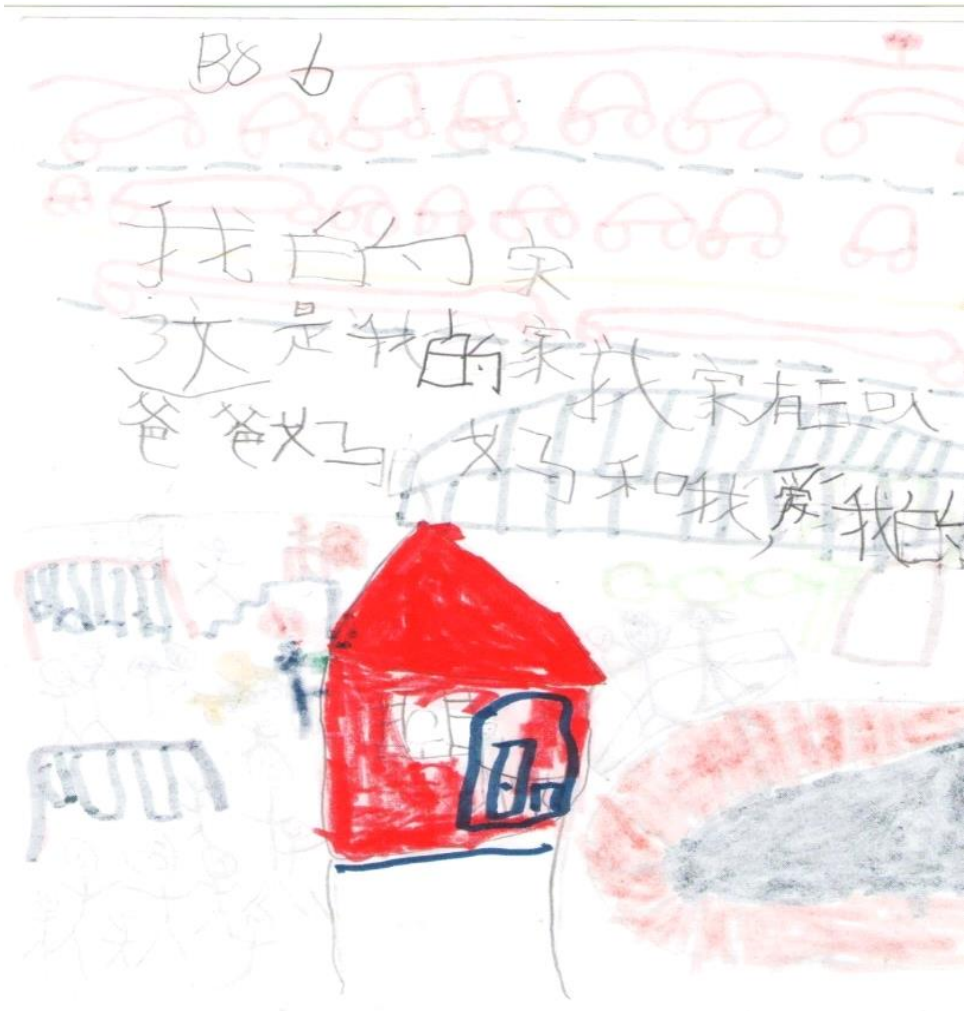

My family

This is my family. There are three people in my family: father, mother, and I. I love my family. 
Appendix B: Making crafts

A little rabbit 小白兔

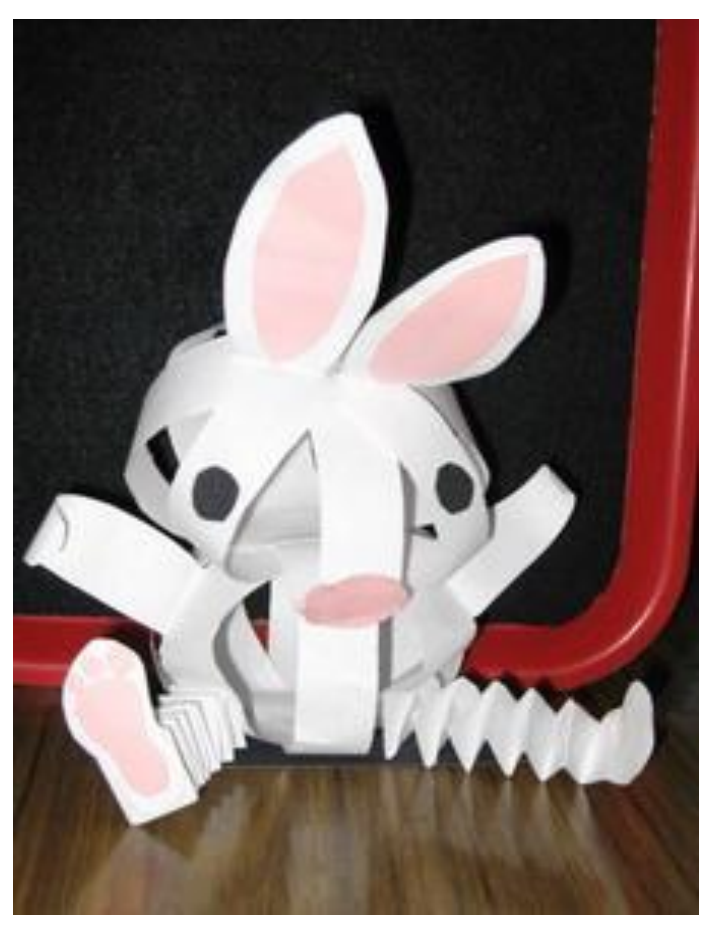




\section{Ladybug 漂虫}

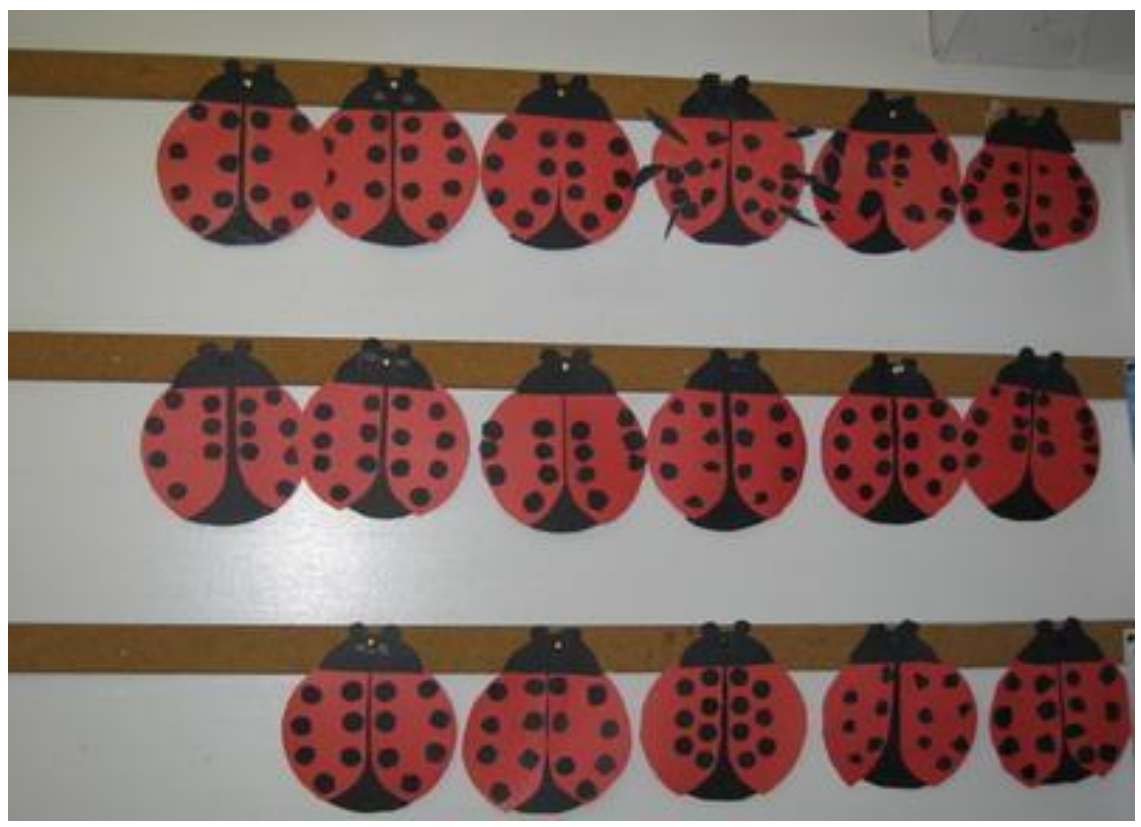

Thank-you cards 感谢卡

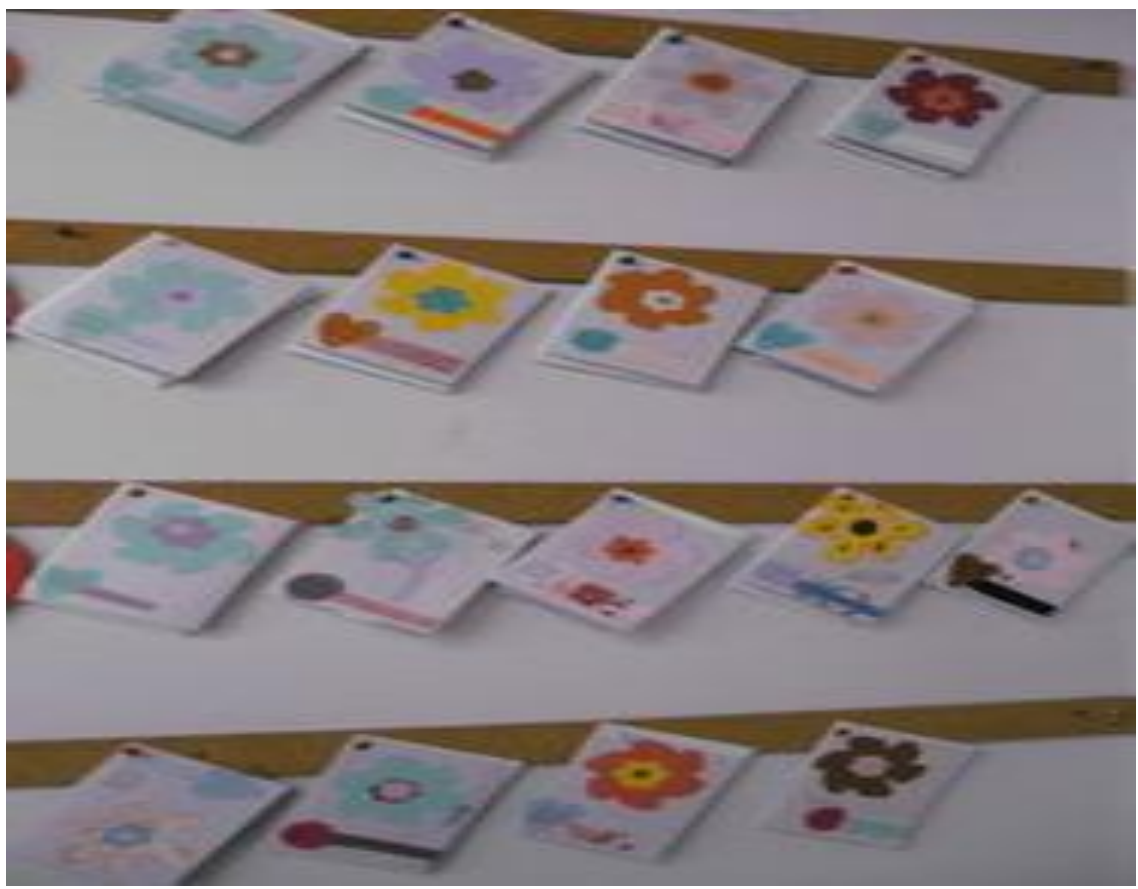


Appendix C: Practicing nursery rhymes

Five Little Monkeys 五只小猴子在床上蹦呀蹦

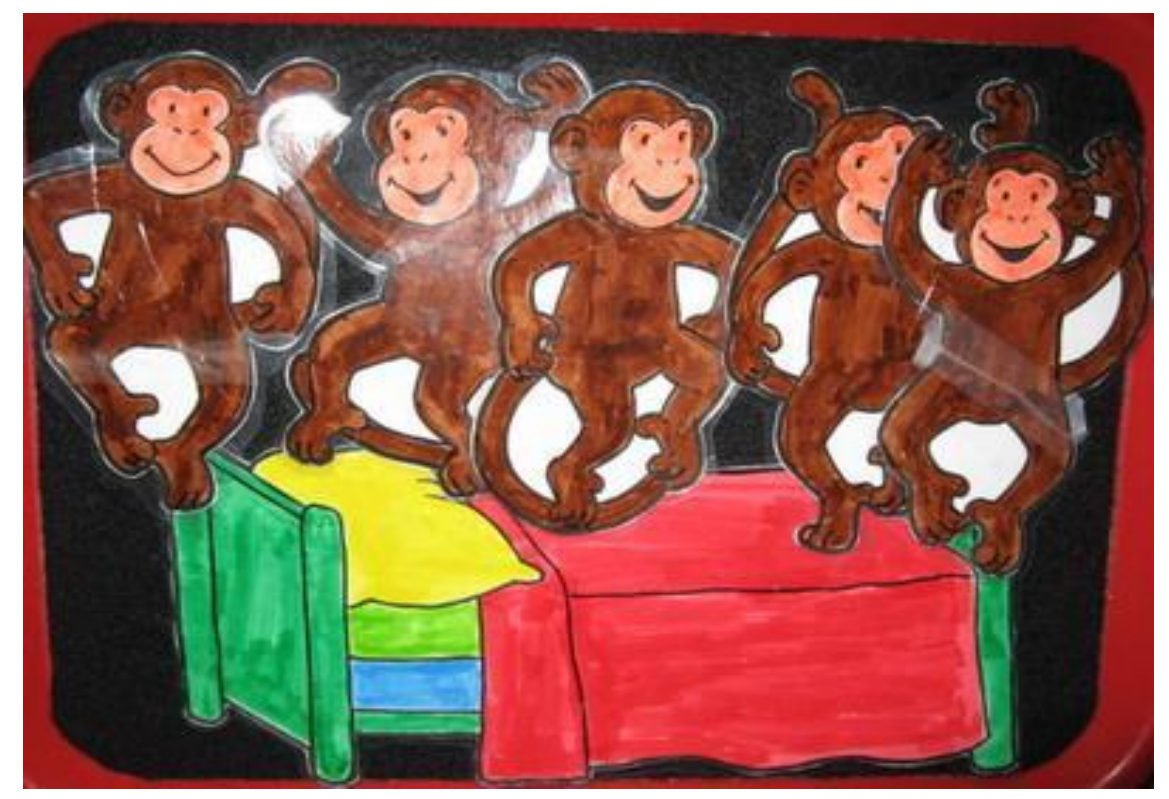

Mr. Alligator 鳄鱼先生

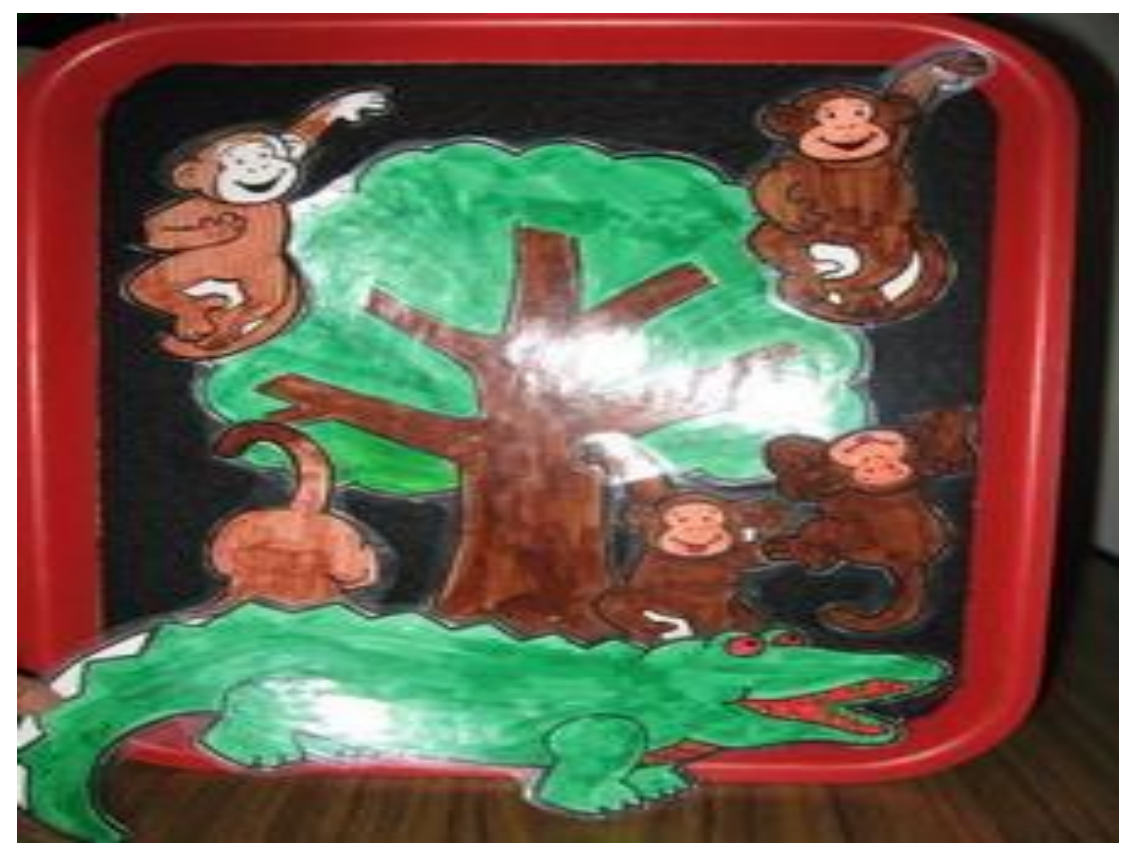

